\title{
A needs-gap analysis of street space allocation
}

\author{
Gabriel Lefebvre-Ropars (corresponding \\ author) \\ Polytechnique Montréal \\ gabriel-lee.lefebvre-ropars@polymtl.ca \\ Paula Negron-Poblete \\ Université de Montréal \\ p.negron-poblete@umontreal.ca
}

\author{
Catherine Morency \\ Polytechnique Montréal \\ cmorency@polymtl.ca
}

\begin{abstract}
Streets have long been designed to maximize motor vehicle throughput, ignoring other street users. Many cities are now reversing this trend and implementing policies to design more equitable streets. However, few existing tools and metrics enable widescale assessment, evaluation, and longitudinal tracking of these street space rebalancing efforts, i.e., assessing how equitable the current street design is, how it can be improved, and how much progress has been made.

This paper develops a needs-gap methodology for assessing the discrepancy between transportation supply and demand in urban streets using existing datasets and automated methods. The share of street space allocated to different street users is measured in 11 boroughs of Montréal, Canada. Travel survey data is used to estimate the observed and potential travel demand in each borough in the AM peak period. A needs-gap analysis is then carried out. It is found that bus riders and cyclists face the greatest needs-gap across the study area, especially in central boroughs. The needs-gap also increases if only trips produced or attracted by a borough are considered. This shows the potential of applying an equity-based framework to the automated assessment of street space allocation in cities using large datasets.
\end{abstract}

\section{Article history:}

Received: May 25, 2020

Received in revised form: June

29, 2020

Accepted: June 29, 2020

Available online: Feb. 2, 2021

\section{Introduction}

Street design in North America has long been determined by the need to maximize traffic fluidity and improve vehicle throughput (Hebbert, 2005). However, cities are increasingly turning to street design policies that benefit all users and consider the street as more than a simple motor vehicle conduit (Hui, Saxe, Roorda, Hess, \& Miller, 2018). Cities like Bordeaux and Berlin, for instance, have declared their intention to rebalance the distribution of public space so that the space allocated to each mode is pegged to its modal share (Berlin's Senate Department for Urban Development and the Environment, 2014; Communauté urbaine de Bordeaux, 2000). Such a normative approach has the effect of allocating every road user a comparable amount of space to move through, based on their observed modal choice. This can be viewed as an application of egalitarianism, where an equitable resource allocation tends towards a uniform distribution among the population (Di Ciommo \& Shiftan, 2017). This approach

Copyright 2021 Gabriel Lefebvre-Ropars, Catherine Morency \& Paula Negron-Poblete http://dx.doi.org/10.5198/jtlu.2021.1808

ISSN: 1938-7849 | Licensed under the Creative Commons Attribution - Noncommercial License 4.0

The Journal of Transport and Land Use is the official journal of the World Society for Transport and Land Use (WSTLUR) and is published and sponsored by the University of Minnesota Center for Transportation Studies. 
is also used by researchers and practitioners who study street space allocation in urban areas (Agentur für clevere Städte, 2014; Colville-Andersen, 2018; Gössling, Schröder, Späth, \& Freytag, 2016; Lee, Sener, \& Jones, 2017; Szell, 2018). Such an egalitarian approach does not take into account the actual space needed by different modes—e.g., cars vs. bicycles—or even vehicle types—e.g., SUVs vs. compact cars (see Bruun \& Vuchic, 1995 for a demonstration of the dynamic space required by each transport mode). Rather, it postulates that space for each mode should be allocated proportionally to the number of people using it, not the number of vehicles or their size.

There are few, if any, explicit frameworks for assessing the progress of these strategies from an equity perspective. Hui et al. (2018) observe that while the Complete Streets approach is gaining popularity around the world, there are no established tools to assess what they call the "completeness of Complete Streets", i.e., the progression of street space allocation towards a more equitable state. A simple tool for evaluating the discrepancy between the needs for a good and its distribution pattern in an egalitarian perspective is the needs-gap analysis. This analysis consists in identifying a needs variable and a supply variable and computing the difference between them (Currie, 2010).

Moreover, few research efforts have tried to study the allocation of street space as a resource dedicated to different transport modes. The literature on street space allocation consists of two approaches: on one hand, an exhaustive, manual measurement approach (Agentur für clevere Städte, 2014; ColvilleAndersen, 2018; Gössling et al., 2016; Hampton, 2013) that accounts for all modes but is hardly scalable to large areas and, on the other hand, an automated approach (Martin, 2016; Szell, 2018; van Liere, Beens, \& Knol, 2017) which leverages large-scale datasets but ignores some transport modes, especially public transit.

This paper seeks to bridge these gaps by evaluating the potential of applying the framework of transportation equity, specifically the distributive justice principle of egalitarianism (Di Ciommo \& Shiftan, 2017), to the problem of street space allocation using automated and exhaustive measurement methods. First, this research examines the current situation of street space allocation in the city of Montréal, Canada. Different time periods and spatial scales are observed in order to take into account the dynamic nature of street space allocation. Then, a needs-gap analysis is carried out at the borough level to assess the equity of street space allocation in the study area when compared with different demand profiles and identify areas in need of priority interventions. 


\section{$2 \quad$ Methods}

\subsection{Study area}

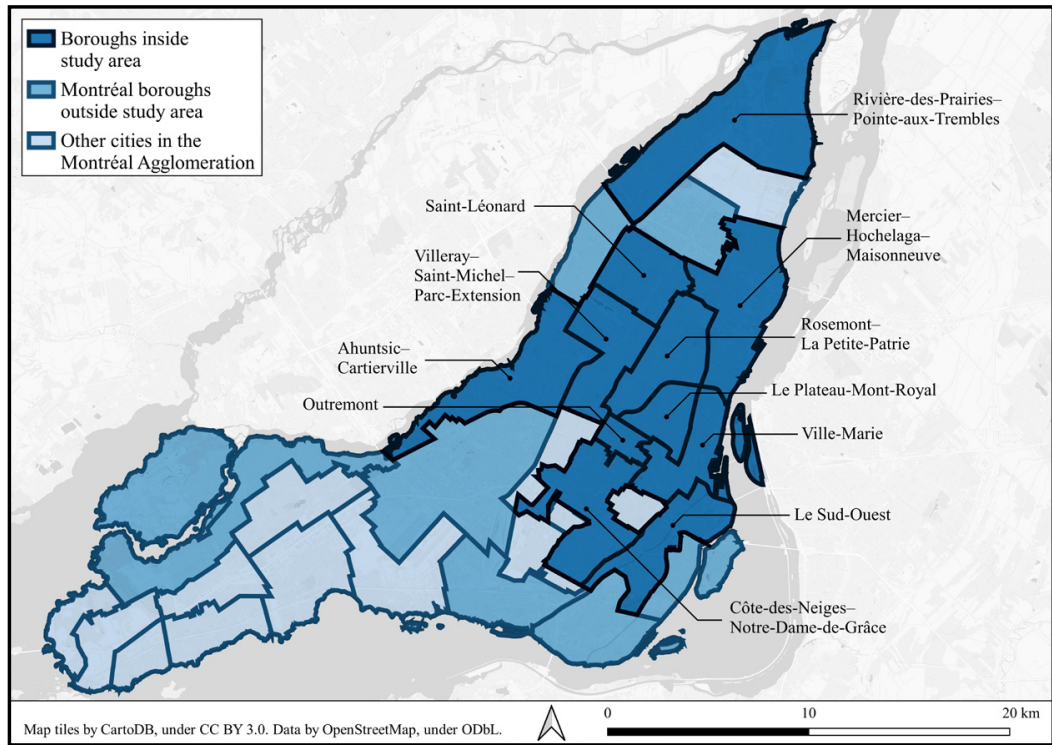

Figure 1. Study area

This paper uses the city of Montréal, in Canada, as a testing ground for the method. Montréal is a city of 1.9 million inhabitants in a metropolitan area of 4 million (Statistics Canada, n.d.). The share of public transit and active modes in Montréal is quite high: on the island of Montréal, 38\% of trips in the AM peak period are carried out by other modes than the private automobile (Secrétariat à l'enquête Origine-Destination, 2015, p. 21).

For reasons of data availability, the selected study area consists of 11 out of the 19 boroughs of the City of Montréal (see Figure 1). The boroughs are listed in Table 1 together with the abbreviation that will be used to refer to them for the rest of this paper. These boroughs account for $44 \%$ of the area of the island of Montréal, $62 \%$ of its population and $49 \%$ of its total linear street length.

Table 1. Boroughs in the study area

\begin{tabular}{|l|l|r|r|}
\hline Borough & Abbreviation & Total linear street length (km) & Share of study area street length \\
\hline Ahuntsic-Cartierville & AC & 358 & $12 \%$ \\
\hline $\begin{array}{l}\text { Côte-des-Neiges- } \\
\text { Notre-Dame-de-Grâce }\end{array}$ & CDN & 293 & $10 \%$ \\
\hline Le Plateau-Mont-Royal & PMR & 162 & $6 \%$ \\
\hline Le Sud-Ouest & SO & 237 & $8 \%$ \\
\hline $\begin{array}{l}\text { Mercier-Hochelaga- } \\
\text { Maisonneuve }\end{array}$ & MHM & 358 & $13 \%$ \\
\hline Outremont & OU & 450 & $2 \%$ \\
\hline $\begin{array}{l}\text { Rivière-des-Prairies- } \\
\text { Pointe-aux-Trembles }\end{array}$ & RDP & 236 & $16 \%$ \\
\hline Rosemont-La Petite-Patrie & RPP & 198 & $8 \%$ \\
\hline Saint-Léonard & SL & 261 & $7 \%$ \\
\hline Ville-Marie & VM & 264 & $9 \%$ \\
\hline $\begin{array}{l}\text { Villeray-Saint-Michel- } \\
\text { Parc-Extension }\end{array}$ & VSP & & $9 \%$ \\
\hline
\end{tabular}




\section{2 \\ Measuring street space allocation}

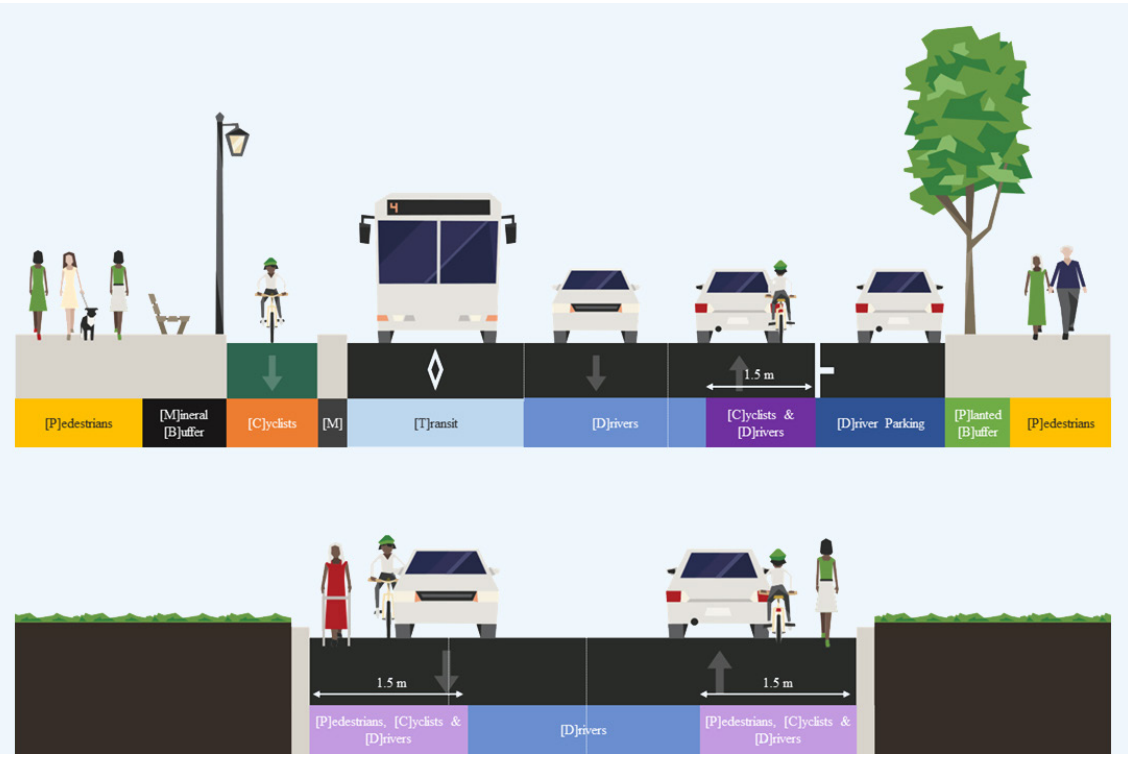

Figure 2. Possible street use categories [Made with StreetMix, CC BY-SA 4.0]

Street space can be allocated in a variety of ways to different transportation- and non-transportation-related uses. The following categories, illustrated in Figure 2, were formalized to allow classifying roadway surfaces for the purposes of this paper:

- [P]edestrians: Space allocated exclusively to pedestrians. Consists of the part of the sidewalk that is not occupied by a buffer zone.

- [C]yclists: Space allocated exclusively to cyclists. Includes segregated bicycle infrastructure as well as painted bike lanes, but not designated lanes (sharrows).

- [C]yclist [P]arking: Space allocated to public bicycle parking facilities as well as BIXI bikeshare stations.

- [C]yclists and [D]rivers: Roadway space shared between cyclists and motorists. Consists of a 1.5-meter wide corridor in the rightmost lane of each street without dedicated cycling infrastructure (segregated path or painted bike lane).

- [P]edestrians, [C]yclists and [D]rivers: Roadway space shared between pedestrians, cyclists and motorists. Consists of a 1.5-meter wide corridor in the rightmost lane of each street without sidewalks and dedicated cycling infrastructure (segregated path or painted bike lane).

- [D] rivers: All remaining roadway space allocated to the movement of motor vehicles.

- [D] river [P]arking: Roadway space allocated to the parking of motor vehicles.

- [C] urb [S]pace: Roadway space located in a parking lane but where parking is not allowed. Includes bus stops, delivery zones and similar areas where personal vehicles may not park.

- [T]ransit: Roadway space allocated exclusively to the movement of public transit vehicles. For the purposes of this paper, this category only includes transit priority lanes.

- [M]edian: Dividers, medians, and other types of similar infrastructure.

- [P]lanted [B] uffer: Sidewalk buffer with trees.

- $[\mathbf{M}]$ ineral [B] uffer: Sidewalk buffer without trees.

In order to classify street surfaces into these categories, a series of open and proprietary datasets, listed in Table 2, is used to build a database of street space allocation on the island of Montréal. The method used in this paper aims to take into account the dynamic nature of street space allocation throughout time and the diversity of uses that public street space can support. 
Table 2. Datasets used in this paper

\begin{tabular}{|c|c|c|c|c|c|}
\hline Dataset & Source & Year & Geometry Type (N) & Attributes used & Open data? \\
\hline Roadway surfaces & $\begin{array}{l}\text { City of Montréal } \\
\text { (Ville de Montréal, n.d.-d) }\end{array}$ & 2019 & Polygon $(111,487)$ & $\begin{array}{l}\text { - Surface type } \\
\text { - Borough } \\
\text { - Roadway } \\
\text { centerline ID } \\
\text { - Construction } \\
\text { year } \\
\end{array}$ & $\begin{array}{l}\text { Yes (except } \\
\text { centerline ID } \\
\text { attribute) }\end{array}$ \\
\hline $\begin{array}{l}\text { Roadway center- } \\
\text { lines }\end{array}$ & $\begin{array}{l}\text { City of Montréal (Ville de } \\
\text { Montréal, n.d.-e) }\end{array}$ & 2019 & $\begin{array}{l}\text { Linestring } \\
(24,001)\end{array}$ & $\begin{array}{l}\text { Number of } \\
\text { directions }\end{array}$ & \\
\hline $\begin{array}{l}\text { Roadway center- } \\
\text { lines }\end{array}$ & Adresses Québec AQpro & 2019 & $\begin{array}{l}\text { Linestring } \\
(23,313)\end{array}$ & $\begin{array}{l}\text { - Posted speed } \\
\text { limit } \\
\end{array}$ & Yes \\
\hline $\begin{array}{l}\text { Traffic model } \\
\text { road network }\end{array}$ & City of Montréal & 2018 & $\begin{array}{l}\text { Linestring } \\
(34,822)\end{array}$ & $\begin{array}{l}\text { - Number of } \\
\text { lanes }\end{array}$ & No \\
\hline Street signs & $\begin{array}{l}\text { City of Montréal } \\
\text { (Ville de Montréal, n.d.-h) }\end{array}$ & 2018 & $\begin{array}{l}\text { Point } \\
(282,374)\end{array}$ & $\begin{array}{l}\text { - Parking restric- } \\
\text { tions } \\
\text { - Activity period } \\
\text { - Type of post } \\
\end{array}$ & No \\
\hline Parking meters & $\begin{array}{l}\text { City of Montréal } \\
\text { (Ville de Montréal, n.d.-i) }\end{array}$ & 2019 & $\begin{array}{l}\text { Point } \\
(66,883)\end{array}$ & $\begin{array}{l}\text { - Parking restric- } \\
\text { tions } \\
\text { - Activity period }\end{array}$ & Yes \\
\hline $\begin{array}{l}\text { Transit priority } \\
\text { and HOV lanes }\end{array}$ & $\begin{array}{l}\text { Ministère des Transports } \\
\text { du Québec (MTQ), exo, } \\
\text { Société de transport de } \\
\text { Montréal (STM) }\end{array}$ & $\begin{array}{l}2017- \\
2019\end{array}$ & $\begin{array}{l}\text { Linestring } \\
(97)\end{array}$ & $\begin{array}{l}\text { - Location on } \\
\text { street } \\
\text { - Activity period }\end{array}$ & Yes \\
\hline Cycling network & $\begin{array}{l}\text { City of Montréal } \\
\text { (Ville de Montréal, n.d.-g) }\end{array}$ & 2018 & $\begin{array}{l}\text { Linestring } \\
(3,654)\end{array}$ & $\begin{array}{l}\text { - Infrastructure } \\
\text { type } \\
\text { - Activity period }\end{array}$ & No \\
\hline BIXI stations & $\begin{array}{l}\text { BIXI } \\
\text { (Ville de Montréal, n.d.-c) }\end{array}$ & 2019 & $\begin{array}{l}\text { Point } \\
(554)\end{array}$ & $\begin{array}{l}\text { - Number of } \\
\text { docks }\end{array}$ & Yes \\
\hline $\begin{array}{l}\text { Public bicycle } \\
\text { racks }\end{array}$ & $\begin{array}{l}\text { City of Montréal } \\
\text { (Ville de Montréal, n.d.-b) }\end{array}$ & 2017 & $\begin{array}{l}\text { Point } \\
(678)\end{array}$ & - Capacity & Yes \\
\hline Public trees & $\begin{array}{l}\text { City of Montréal } \\
\text { (Ville de Montréal, n.d.-a) }\end{array}$ & 2018 & $\begin{array}{l}\text { Point } \\
(269,237)\end{array}$ & $\begin{array}{l}\text { - Position on } \\
\text { street } \\
\text { - Year of plant- } \\
\text { ing }\end{array}$ & Yes \\
\hline $\begin{array}{l}\text { Tree canopy and } \\
\text { land cover }\end{array}$ & $\begin{array}{l}\text { Communauté métropolit- } \\
\text { aine de Montréal (CMM) } \\
\text { (Communauté métropoli- } \\
\text { taine de Montréal, n.d.) }\end{array}$ & 2017 & $\begin{array}{l}\text { Polygon } \\
(1,630,430)\end{array}$ & $\begin{array}{l}\text { - Land cover } \\
\text { category }\end{array}$ & Yes \\
\hline $\begin{array}{l}\text { City and borough } \\
\text { limits }\end{array}$ & $\begin{array}{l}\text { City of Montréal } \\
\text { (Ville de Montréal, n.d.-f) }\end{array}$ & 2019 & $\begin{array}{l}\text { Polygon } \\
(11)\end{array}$ & - Borough name & Yes \\
\hline $\begin{array}{l}2013 \text { Origine-Des- } \\
\text { tination Survey, } \\
\text { v13.2b }\end{array}$ & $\begin{array}{l}\text { Autorité régionale de trans- } \\
\text { port métropolitain (ARTM) }\end{array}$ & 2013 & $\begin{array}{l}\text { Point } \\
\text { (180,174 trip } \\
\text { observations) }\end{array}$ & $\begin{array}{l}\text { - Trip origin and } \\
\text { destination } \\
\text { - Mode used for } \\
\text { the trip } \\
\text { - Departure time } \\
\text { of trip }\end{array}$ & No \\
\hline $\begin{array}{l}\text { Census of the } \\
\text { Population }\end{array}$ & Statistics Canada & 2016 & $\begin{array}{l}\text { Polygon } \\
(422)\end{array}$ & $\begin{array}{l}\text { Population at } \\
\text { the census tract } \\
\text { level }\end{array}$ & No \\
\hline
\end{tabular}


A roadway surfaces inventory developed by the City of Montréal serves as the foundation of this analysis. This inventory classifies street surfaces into different categories, including sidewalks, cycle paths, medians, roadways and intersections. Each street surface is also associated with the corresponding street centerline geometry using a common street ID attribute. Through a series of spatial joins in a spatially enabled PostgreSQL 10.9/PostGIS 2.5.2 database, several attributes from other databases are associated with each street segment (see Table 2). It is thus possible to know, for each street segment: the posted speed limit, the number of parking and driving lanes and their operating hours and restrictions, the number of BIXI bikeshare docks, the location and operating parameters of transit priority lanes as well as the opening and closing dates of the cycle network.

A particularity of the City of Montréal's road surfaces inventory is that sidewalk geometries do not make a difference between the walkable portion of the sidewalk and the buffer zone, usually located next to the roadway, where trees and street furniture are located. The location and shape of these buffer zones thus have to be estimated. A unidirectional buffer geometry around the curb side limit of the sidewalk is created for each sidewalk where trees or signposts are detected. Due to the imprecise geolocation of trees and signposts in the public datasets, their position on the sidewalk could not be used to determine the buffer width. As an approximation of the average sidewalk buffer size, a uniform buffer size equal to $33 \%$ of the average width of the sidewalk is used. This value was derived from observations carried out on a series of streets in the study area using satellite imagery. Buffers created on a sidewalk with trees are classified as planted buffers, while those on sidewalks with only signposts are classified as mineral buffers. No buffer is created for sidewalks where no trees or signposts are detected.

In order to enable the simultaneous treatment of linear street elements like lanes and point data like bikeshare docks and bicycle parking racks, a surface footprint is calculated for each street segment, excluding intersections. To simplify calculations, each street segment is divided longitudinally into 3-meter segments. This length was chosen because it reduces the computational burden while preserving a granularity that allows capturing variations in street space allocation-parking regulations that apply to a single parking spot, for instance. Perpendicular axes are created at 3-meter intervals on street segment centerlines and given a sequential order. The width of every street surface type is calculated for each axis and ordered according to their position. The surface area for each street surface type, for each axis, can then be calculated by multiplying its width by 3 . It should be noted that this method can create slight distortions in curved streets, since the distance between perpendicular axes varies according to the lateral position of the surface in question. Given the aggregation level of the data used in later steps of this paper, this has been considered as an acceptable imprecision level.

For any chosen half-hour period in the reference year, it is then possible to infer the number of traffic lanes, parking lanes, transit lanes and cycle lanes on each perpendicular axis according to data extracted from parking signs as well as the transit priority and cycling networks. An illustration of this method is shown above in Figure 3.

Once the characteristics of a given street segment are known, it is possible to calculate the surface area allocated to several categories of street users and usages for any given street in the study area. 

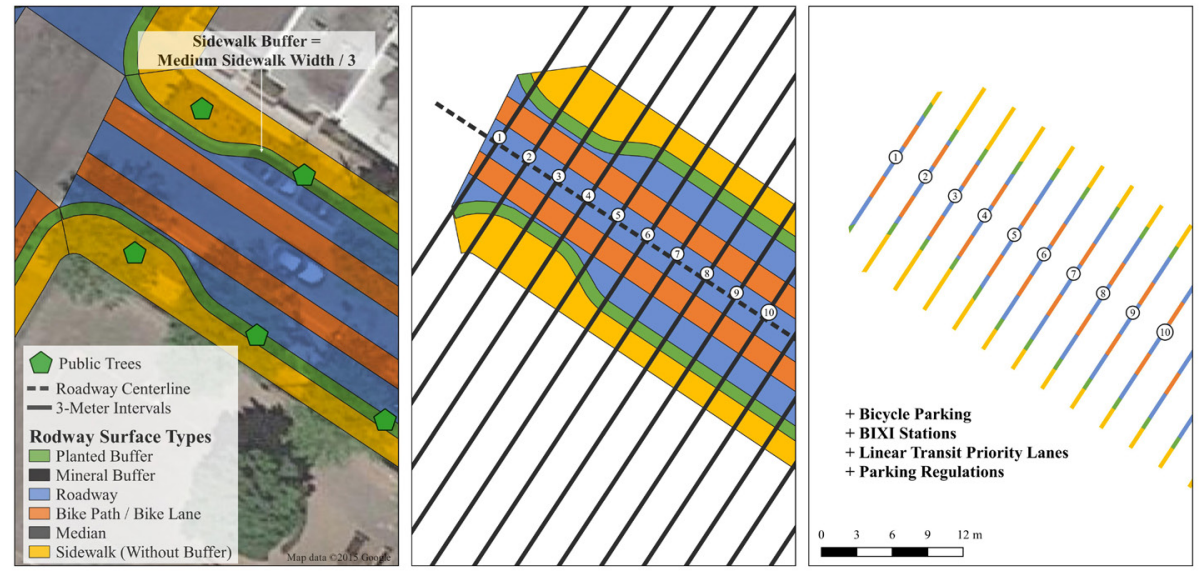

Figure 3. Measuring the width of different street surfaces for each segment

Since the status of parking lanes, bicycle lanes, transit priority lanes and BIXI bikeshare stations varies during the year, this paper focuses on a single date, September 3,2018, although this analysis could be repeated for any other date.

\subsection{Estimating observed and potential street demand at the borough scale}

The number of trips passing through each borough of the study area is estimated using the 2013 Origine-Destination (OD) survey data. The 2013 OD survey is the latest available version of a quinquennial household travel survey that covers the Montréal metropolitan area. The OD survey samples around $4 \%$ of metropolitan households and collects information on households and their members as well as the trips they carried out on the business day before the survey date. Information is collected on different household-, person- and trip-level attributes. Survey responses are weighted to represent the total population, with 410,741 surveyed trips representing almost 9.4 million actual trips on an average fall weekday (exo, n.d.).

In the present case, information on the origin and destination of trips, their declared departure time and the mode used for the trip are extracted from the OD survey database. For each survey record where a trip has been carried out, the shortest-path itinerary between origin and destination is calculated using the OSRM routing tool (Luxen \& Vetter, 2011) with customized routing profiles as well as the trRouting public transit routing algorithm (Bourbonnais, 2019). Itineraries are calculated for 4 different modes for each trip record: driving, public transit, cycling and walking. Driving itineraries are calculated in OSRM using a network where links are weighted with driving times that reflect the intensity of congestion at the declared time of departure. The in-vehicle segments of public transit trips are simulated in trRouting using the GTFS planned service data from the fall 2017 service period. Commuter train and subway trip legs are ignored since they take place off-street. The access and egress segments of public transit trips- from the origin to the first boarding stop and from the last alighting stop to the destination-are calculated in OSRM and considered as walking trips. Cycling itineraries use an OSRM custom profile that considers factors such as the slope and the presence of cycling infrastructure.

It should be kept in mind that these simulations do not necessarily represent the actual itineraries used by survey respondents, but a modeled demand based on plausible itineraries calculated using different hypotheses. The phrase "observed demand" used in the rest of this paper should be interpreted as shorthand for "calculated itineraries for observed trip origins and destinations." Moreover, since this 
demand is not the result of an equilibrium-based travel demand model but rather of a weighted all-ornothing assignment, it is impossible to assess the validity of calculated traffic volumes on individual street segments. For instance, the modeled volume on a given street segment might exceed its capacity while there might be no trips assigned to a parallel street segment with equivalent characteristics. For this reason, trips are aggregated at a borough scale to smooth out such effects.

Observed street demand for a given borough is defined as the sum of all passenger-kilometers traveled (PKT) in a given borough, per mode. This demand is calculated for every borough B and mode $\mathrm{M}$ as shown in Equation 1:

$P K T_{B, M}=\sum_{i \mid m_{i}=M} \ell\left(g_{i} \cap g_{B}\right) * W_{i}$

Where $i$ is a trip record, $m_{i}$ its declared mode, $W_{i}$ its survey weight and $g_{i}$ the polyline geometry of its itinerary, while $g_{B}$ is the geometry of borough $B$ and $\ell(x)$ represents the calculation of a geometric length in kilometers.

Four modes $M$ are considered in this paper: driving (includes passengers), on-street public transit, cycling and walking. For each borough-trip combination, trips are tagged as "internal" if their origin and destination lie within the borough, "produced" or "attracted" if the origin or the destination, respectively, is located in the borough, or "external" if both of these points lie outside the borough.

Potential street demand for a given borough is defined as the potential demand profile that could be observed if, in addition to observed active trips, all car and publics transit trips that are practicable by walking or cycling were carried out using active modes. For each motorized trip in the OD survey database, a series of criteria - age/gender of the person, length of the trip, structure of the trip chain, purpose of the trip - are evaluated to assess if the trip could realistically be carried out by walking or cycling (Morency, Verreault, \& Frappier, 2019). Motorized trips that fit in these criteria are considered latent active trips. The potential demand profile thus includes the following trips:

- Observed pedestrian and cycling trips

- Latent pedestrian and cycling trips

- Observed car and public transit trips that do not qualify as latent active trips

The calculated itineraries corresponding to the potential demand profile are then used to compute a mode share for each borough using the same method as for observed street demand (see Equation 1), substituting the declared mode with the potential mode, as well as to determine the trip type (internal, external, attracted or produced). For the purposes of this paper, only trips carried out in the AM peak period (6:00 AM to 9:00 AM) are studied, although the same analyses could be applied to other time periods.

\section{$2.4 \quad$ Needs-gap analysis}

Once both street space supply—i.e., street space allocation for each mode—and demand-i.e., observed and potential trips going through boroughs of the study area- have been computed, they can be compared in order to assess the gap between them. In line with the egalitarian approach of street space allocation (Agentur für clevere Städte, 2014; Colville-Andersen, 2018; Gössling et al., 2016; Szell, 2018), the share of street space allocated to transportation modes is compared with the corresponding observed and potential modal share.

The total area allocated to each street use category is calculated for each borough. Street space 
dedicated to transportation uses includes categories D, DP, T, C, CP, P, CD and PCD as illustrated in Figure 2. Sidewalk buffers and medians are not considered as transportation space for the purposes of this paper.

For each borough, the total number of trips per mode is calculated for each type of trip (internal, external, produced and attracted) and for each period of the day. Trips in a borough are weighted by the length of the calculated itinerary that intersects the borough in order to represent the total demand across the borough streets in the form of passenger-kilometers traveled (PKTs).

A needs-gap index $(G)$ for each mode $M$ is then calculated by subtracting the share (\%) of mode $M$ $\left(D_{M}\right)$ from the share (\%) of total space supply for mode $M\left(S_{M}\right)$, as shown in Equation 2:

$G_{M}=S_{M}-D_{M}$

\section{$3 \quad$ Results}

\subsection{Variations in street space allocation within the study area}

Figure 4 shows the share of street space allocated to each mode and use of the street in the 11 boroughs of the study area during the AM peak half-hour (8:00 AM to 8:30 AM). The surface area allocated to the exclusive use of cyclists and public transit is very low across the study area, ranging from $0.5 \%$ (SL) to $3.2 \%$ (RPP). In contrast, half of the total surface area of each borough (48\% to $55 \%$ ) is allocated to drivers in the AM peak period, as well as between 14\% to $18 \%$ to on-street vehicle parking (except in the $\mathrm{VM}$ and OU boroughs, where this proportion falls down to $7 \%$ of the total street area, most likely due to parking lanes being converted to driving lanes in peak periods).

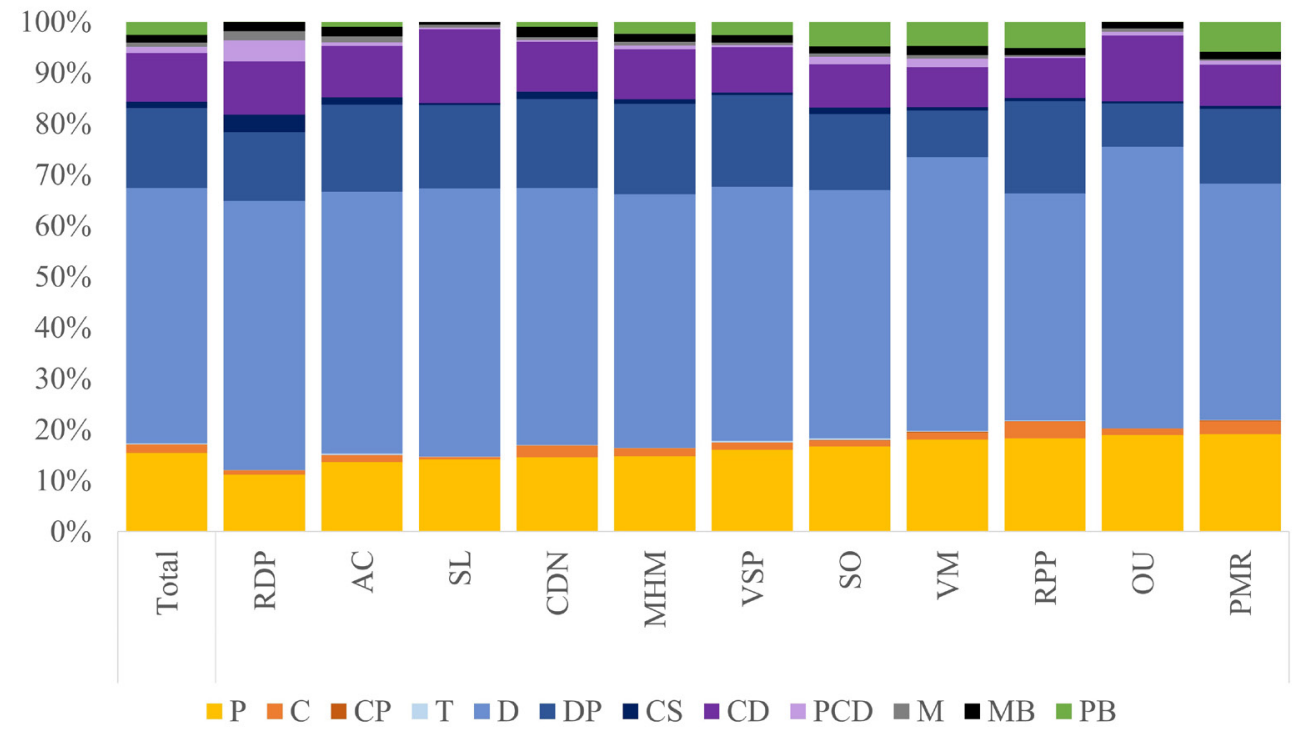

Figure 4. Distribution of street area per borough, per mode and mode combination, AM peak period on a weekday 
The peripheral boroughs of RDP, AC and SL, as well as the central neighborhoods of CDN and $\mathrm{MHM}$, allocate less street area to exclusive pedestrian infrastructure $[\mathrm{P}]$ than the average of $15.4 \%$ for the study area. These boroughs, together with OU, also provide street users with few planted buffers.

Overall, the boroughs of SL and OU are those that offer the least amount of dedicated space to cyclists, which explains the inversely proportional part of space shared between cyclists and drivers [CD]. The RDP borough, a mostly suburban area, shows the highest proportion of street space shared between pedestrians, cyclists and drivers [PCD], indicating that several residential streets in the borough do not have any dedicated pedestrian infrastructure. The significant presence of PCD space in the central SO and VM boroughs, on the other hand, is mostly due to the presence of industrial areas and service roads and to the absence of sidewalks on the road network of the Jean-Drapeau park. It should be noted that a bike path is present on the city's Formula 1 circuit, but this path does not appear in the roadway inventory dataset since it is only separated from automobile traffic with temporary bollards. This is a known limitation of the street surface allocation detection tools used in this paper.

\subsection{Temporal variations in street space allocation}

Street space allocation is dynamic and can vary according to the month, the day or even the time of day. Parking regulations and transit priority lane operations can have an important effect on the distribution of street space within a day. Figure 5 shows the variation in total surface area for different roadway uses for 4 periods on a weekday (Monday, September 3, 2018) in the Ville-Marie (VM) borough, which encompasses downtown Montréal. The reference period in this chart is the first period, 4:00 AM to 4:30 AM.

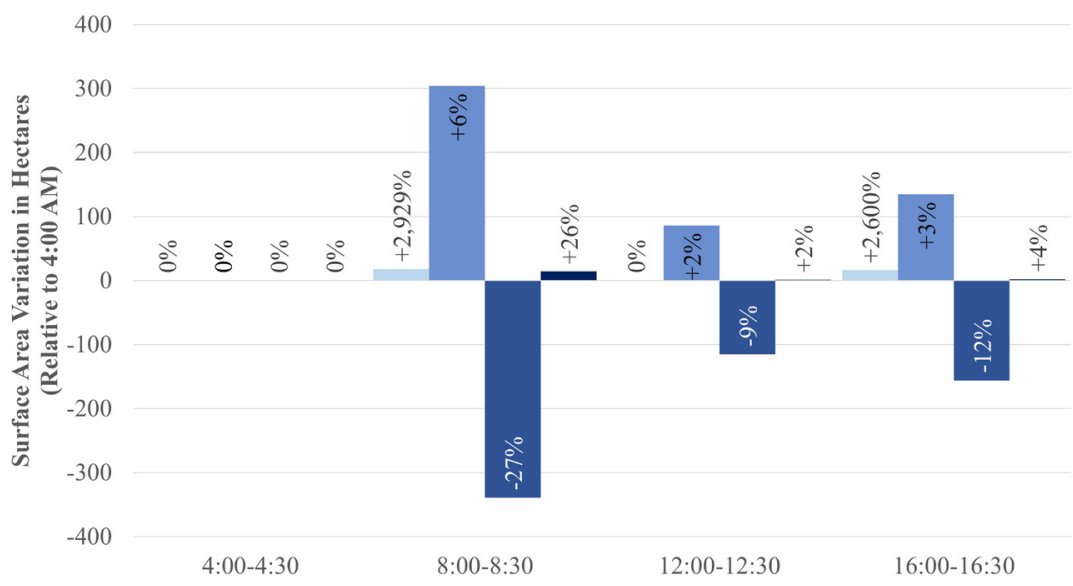

Figure 5. Variations in street space allocation in the Ville-Marie (downtown) borough during a weekday

The largest variation in street space allocation for motorized modes occurs during the AM peak period. At 8:00 AM, on-street parking capacity in the Ville-Marie borough is decreased by $27 \%$, just over 6,300 parking spaces. Most of that space, which represents over 300 hectares of public space, is dedicated to drivers by adding extra driving lanes on several downtown streets. A small increase in "other" curb space [CS] is also visible, a category which includes delivery zones and other types of restricted parking areas.

Most of this space returns to driver parking after the AM peak period is over. The midday and PM peak periods seem to rely less on the reduction of parking space to accommodate drivers, with respectively 85 and 135 hectares of street space, or around 2,000 and 3,000 parking spaces, transferred 
to drivers.

In comparison, the total area allocated to transit priority lanes in the AM and PM peak periods across the whole borough represents respectively around $6 \%$ and $12 \%$ of the extra space allocated to drivers. This contrasts with the mode share of both modes, with bus trips originating or ending in the downtown area for the same periods representing $28 \%$ of all on-street motorized trips (cars and buses) produced or attracted by the area.

\subsection{Needs-gap analysis of street space supply and demand}

The relationship between transportation demand and supply is not uniform across the study area. Table 3 and Figure 6 present the needs-gap for each mode $\left(G_{i}\right)$ in the study area as well as in each of the 11 boroughs. Transportation supply and demand in this context are understood respectively as the portion of street space area allocated to a given mode $\left(S_{i}\right)$ for the 8:00 AM to 8:30 AM period on the reference date and the demand profile of the corresponding mode $\left(D_{i}\right)$ for observed or potential trips intersecting the borough in the AM peak period (6:00 AM to 9:00 AM).

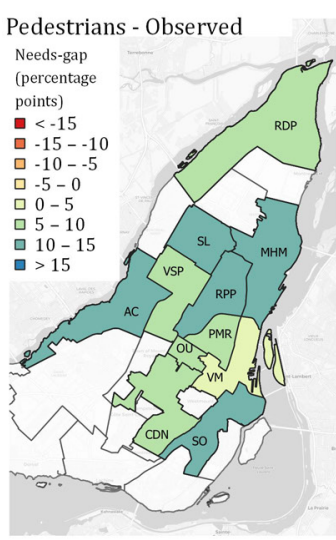

Transit users - Observed

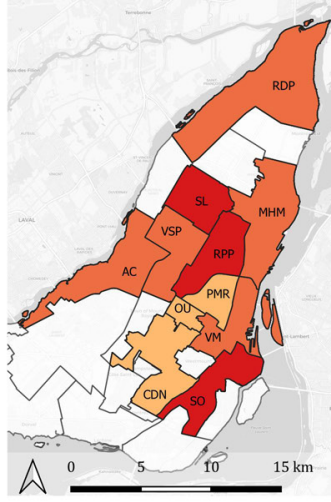

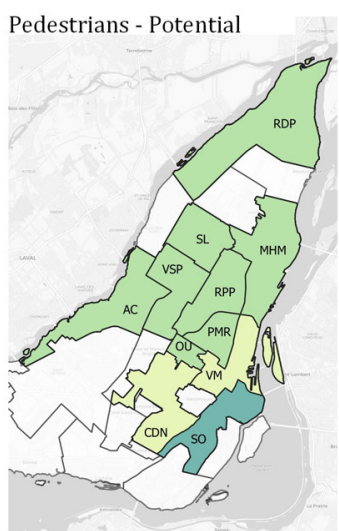

Transit users - Potential

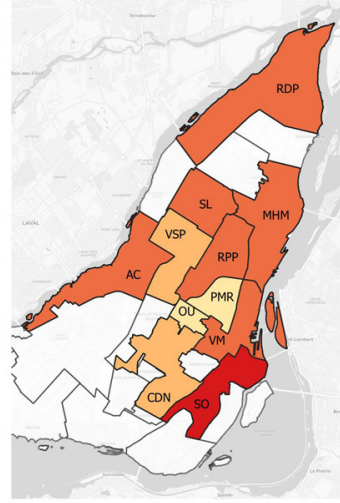

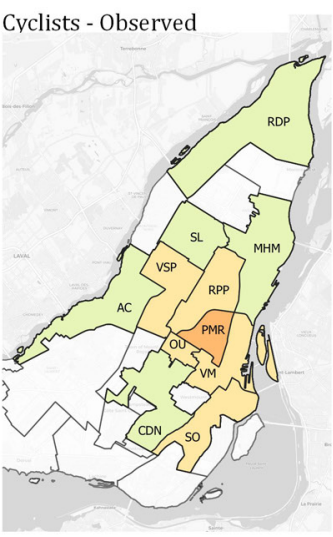

Drivers - Observed

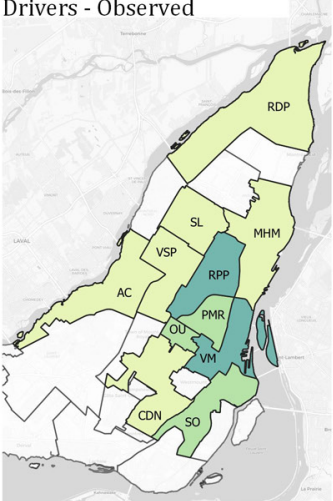

Cyclists - Potential

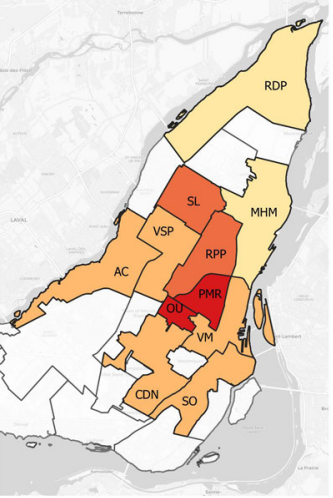

Drivers - Potential

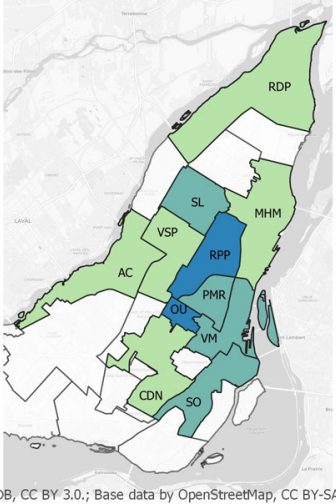

Figure 6. Spatial distribution of the needs-gap, per mode, AM peak period on a weekday

The proportion of surface area allocated to pedestrians across the whole study area is higher than the observed share of pedestrian PKTs, while the proportion of exclusive cycling space is $50 \%$ lower than the observed share of cyclist PKTs. When looking at exclusive transit space, i.e., bus priority lanes, they represent a meager $0.2 \%$ portion of the total street surface in the study area while bus riders make up $14 \%$ of observed PKTs. This leads to a major gap in the needs-gap index. Conversely, the proportion 
of street space allocated to car drivers (and passengers) is higher than the associated observed demand.

When looking at the potential demand profile, which represents the potential for active modes for trips recorded in the 2013 OD survey, the gap becomes more obvious: pedestrian supply is still higher than potential needs, but cycling space is notably underrepresented with a gap of 7 percentage points. Due to the transfer of some motorized trips towards active modes, the needs-gap is reduced for transit but increased for drivers.

Table 3. Needs-gap analysis of street space allocation in the study area, AM peak period on a weekday

\begin{tabular}{|c|c|c|c|c|c|c|c|c|c|c|c|c|c|}
\hline \multirow{2}{*}{$\begin{array}{l}P=\text { PEDESTRIANS } \\
C=\text { CYCLISTS } \\
\text { Borough }\end{array}$} & \multirow{2}{*}{$\begin{array}{l}\mathrm{T}=\text { TRANSIT USERS } \\
\mathrm{D}=\text { DRIVERS } \\
\text { Demand Profile }\end{array}$} & \multicolumn{4}{|c|}{$\begin{array}{l}\text { Demand }\left(D_{i}\right) \\
\% \text { OF PKTS }\end{array}$} & \multicolumn{4}{|c|}{$\begin{array}{c}\text { Supply }\left(\boldsymbol{S}_{i}\right) \\
\% \text { OF SURFACE }\end{array}$} & \multicolumn{4}{|c|}{$\begin{array}{c}\text { Needs-Gap }\left(\boldsymbol{G}_{i}\right) \\
\text { PERCENTAGE POINTS }\end{array}$} \\
\hline & & $\mathbf{P}$ & $\mathrm{C}$ & $\mathbf{T}$ & D & $\mathbf{P}$ & C & $\mathbf{T}$ & D & $\mathbf{P}$ & C & $\mathbf{T}$ & D \\
\hline \multirow{2}{*}{ STUDY AREA } & Observed & 7.4 & 2.7 & 14.0 & 75.9 & 16.4 & 1.8 & 0.2 & 81.6 & +9.0 & -0.9 & -13.8 & +5.6 \\
\hline & Potential & 8.0 & 9.3 & 11.6 & 71.2 & $"$ & $"$ & $"$ & $"$ & +8.4 & -7.4 & -11.4 & +10.4 \\
\hline \multirow{2}{*}{ AC } & Observed & 4.1 & 1.4 & 13.6 & 80.9 & 14.4 & 1.5 & 0.3 & 83.8 & +10.3 & +0.1 & -13.3 & +2.9 \\
\hline & Potential & 4.5 & 6.4 & 11.5 & 77.5 & $"$ & $"$ & $"$ & $"$ & +9.9 & -5.0 & -11.2 & +6.2 \\
\hline \multirow{2}{*}{ CDN } & Observed & 10.0 & 1.8 & 9.9 & 78.2 & 15.3 & 2.5 & 0.1 & 82.1 & +5.3 & +0.6 & -9.9 & +3.9 \\
\hline & Potential & 10.9 & 10.2 & 6.6 & 72.3 & $"$ & $"$ & $"$ & $"$ & +4.5 & -7.7 & -6.5 & +9.8 \\
\hline \multirow{2}{*}{ МНM } & Observed & 5.5 & 1.2 & 13.2 & 80.2 & 15.6 & 1.7 & 0.1 & 82.6 & +10.2 & +0.5 & -13.1 & +2.4 \\
\hline & Potential & 5.9 & 6.1 & 11.8 & 76.3 & $"$ & $"$ & $"$ & $"$ & +9.8 & -4.3 & -11.8 & +6.3 \\
\hline \multirow{2}{*}{$\mathbf{O U}$} & Observed & 11.7 & 6.1 & 9.7 & 72.5 & 19.4 & 1.3 & 0.0 & 79.3 & +7.7 & -4.8 & -9.7 & +6.8 \\
\hline & Potential & 13.2 & 22.0 & 4.4 & 60.5 & $"$ & $"$ & $"$ & $"$ & +6.2 & -20.6 & -4.4 & +18.8 \\
\hline \multirow{2}{*}{ PMR } & Observed & 11.0 & 10.3 & 9.6 & 69.2 & 20.8 & 2.9 & 0.1 & 76.1 & +9.8 & -7.3 & -9.5 & +7.0 \\
\hline & Potential & 11.9 & 18.9 & 4.6 & 64.6 & $"$ & $"$ & $"$ & $"$ & +8.9 & -16.0 & -4.5 & +11.5 \\
\hline \multirow{2}{*}{ RDP } & Observed & 2.5 & 0.3 & 14.0 & 83.2 & 12.0 & 1.0 & 0.0 & 87.0 & +9.5 & +0.7 & -14.0 & +3.8 \\
\hline & Potential & 2.9 & 4.3 & 12.9 & 79.9 & $"$ & $"$ & $"$ & " & +9.1 & -3.3 & -12.9 & +7.1 \\
\hline \multirow{2}{*}{ RPP } & Observed & 8.6 & 5.8 & 19.7 & 65.9 & 19.8 & 3.6 & 0.2 & 76.4 & +11.1 & -2.2 & -19.5 & +10.5 \\
\hline & Potential & 9.8 & 18.4 & 14.2 & 57.7 & $"$ & $"$ & $"$ & " & +10.0 & -14.8 & -13.9 & +18.7 \\
\hline \multirow{2}{*}{ SL } & Observed & 4.1 & 0.3 & 15.2 & 80.4 & 14.4 & 0.5 & 0.1 & 85.0 & +10.3 & +0.1 & -15.1 & +4.6 \\
\hline & Potential & 5.0 & 10.9 & 12.5 & 71.6 & $"$ & $"$ & $"$ & $"$ & +9.4 & -10.4 & -12.4 & +13.4 \\
\hline \multirow{2}{*}{ So } & Observed & 4.1 & 2.3 & 22.0 & 71.6 & 18.2 & 1.3 & 0.4 & 80.1 & +14.1 & -0.9 & -21.6 & +8.4 \\
\hline & Potential & 4.4 & 7.3 & 21.3 & 67.0 & $"$ & $"$ & $"$ & $"$ & +13.8 & -6.0 & -20.9 & +13.1 \\
\hline \multirow{2}{*}{ VM } & Observed & 14.7 & 4.4 & 12.8 & 68.2 & 19.6 & 1.6 & 0.2 & 78.6 & +4.9 & -2.7 & -12.6 & +10.4 \\
\hline & Potential & 15.2 & 9.4 & 11.2 & 64.2 & $"$ & $"$ & $"$ & $"$ & +4.4 & -7.7 & -11.0 & +14.3 \\
\hline \multirow{2}{*}{ VSP } & Observed & 7.5 & 2.2 & 12.7 & 77.5 & 16.9 & 1.6 & 0.2 & 81.3 & +9.3 & -0.7 & -12.5 & +3.8 \\
\hline & Potential & 8.4 & 9.3 & 9.7 & 72.7 & $"$ & $"$ & $"$ & " & +8.5 & -7.7 & -9.4 & +8.6 \\
\hline
\end{tabular}

The needs-gap between cycling space and observed demand is positive in 4 boroughs: $\mathrm{AC}$ and $\mathrm{CDN}$, dense boroughs somewhat removed from downtown, as well as RDP and SL, boroughs with a suburban structure, which means that exclusive cycling space is overrepresented when compared to the observed share of cycling PKTs. In all other boroughs, this relationship is inverted: exclusive cycling space is underrepresented when compared to the share of observed PKTs. This is most evident in the PMR borough, a dense, mixed-use, downtown-adjacent borough with the highest share of observed cycling PKTs (10.3\%) among all boroughs. Looking at the potential demand profile for cycling reinforces this observation, with the gap reaching over 15 percentage points in 3 boroughs with a strong cycling potential (OU, PMR and RPP).

\subsection{Influence of trip types on the needs-gap analysis}

Figure 7 shows an example of a comparison between transportation supply and demand in the VilleMarie (downtown) borough for both the observed and potential demand profiles. In the AM peak period, $79.5 \%$ of street space dedicated to transportation uses (excluding buffer zones and medians) is 
allocated to drivers, whether parked or in motion. Another $19.5 \%$ is allocated exclusively to pedestrians, while the remaining $1 \%$ is allocated to the exclusive use of cyclists, parked or in motion.

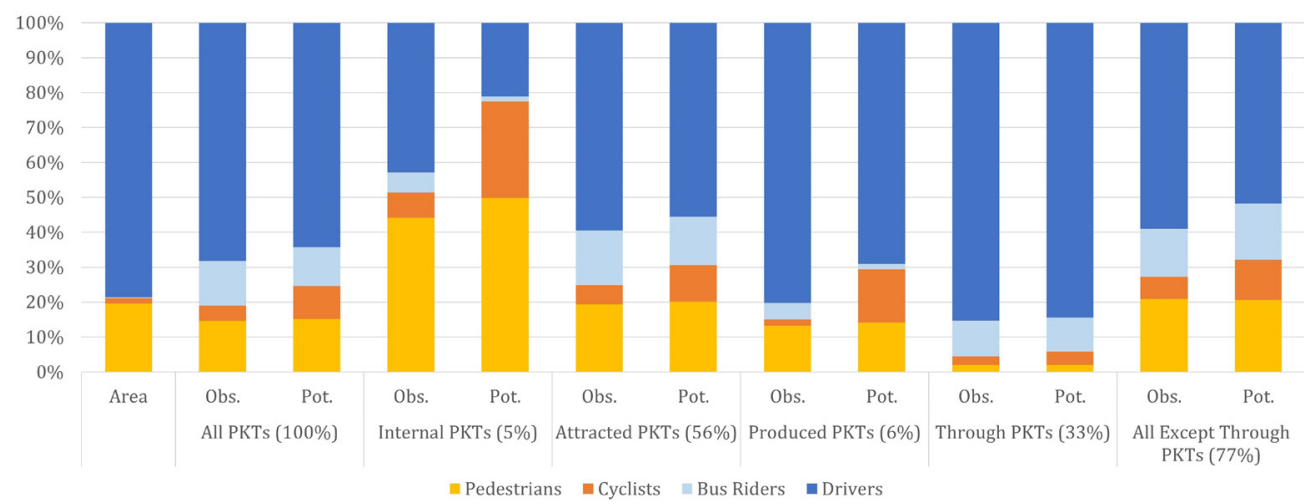

Figure 7. Needs-gap analysis of street space allocation in the Ville-Marie (downtown) borough per trip type during the AM peak period on a weekday

In comparison, drivers and their passengers represent $68.2 \%$ of all observed passenger-kilometers traveled (PKTs) in the borough and pedestrians, 14.7\%. Cyclists represent 4.3\% of observed PKTs, a value roughly 4 times greater than the percentage of the street surface area exclusively allocated to them. The gap between PKTs and street space is even larger when considering potential cycling PKTs, i.e., observed cycling trips as well as motorized trips that could plausibly be carried out by cycling. Potential cycling PKTs represent $9.35 \%$ of total potential PKTs during the morning peak in the Ville-Marie borough, which is almost 10 times greater than the portion of public street space exclusively allocated to parked or moving bicycles. Conversely, the portion of street space allocated to pedestrians is larger than both the proportion of observed and potential pedestrian PKTs.

Analyzing different types of trips brings some nuance to these findings. When looking only at internal PKTs, for instance, i.e., PKTs from trips that are entirely carried out within the same borough, the relationship between street space supply and needs changes. For all boroughs but the suburban RDP, the portion of street space allocated to pedestrians is lower than the portion of PKTs (observed and potential) carried out by pedestrians. In Ville-Marie, as shown in Figure 7, 44.2\% of observed internal PKTs are carried out by pedestrians in the AM peak period, which is over two times greater than the proportion of pedestrian street space.

When looking at all trips except through trips, the picture varies between central and peripheral boroughs. For instance, in central boroughs (CDN, PMR, SO, MHM, OU, RPP, VM and VSP), the proportion of both observed and potential pedestrian PKTs is higher than the corresponding proportion of the street surface area, whereas the opposite is true for peripheral boroughs (AC, RDP, SL).

\section{Discussion}

\subsection{Street space allocation in the study area}

The portrait of space allocation varies from one borough to another and varies the most between boroughs that have been part of the City of Montréal for a long time and former suburban municipalities which were merged with the City of Montréal in the last 50 years. For instance, it is possible to observe a disparity in the provision of planted street buffers between, on one hand, the former independent cities 
of SL, OU and RDP and, on the other hand, the remaining boroughs in the study area. Planted buffers are almost non-existent in former independent cities (trees are rather planted in front of buildings, on private properties), while they are frequent in older boroughs. This seems to result from different greening strategies: the construction year attribute in the public trees dataset shows a steadily increasing number of trees being planted on sidewalks since the 1980s in the central boroughs. The absence of planted buffers often results in narrower sidewalks and less perceived protection from vehicular traffic, which can reduce their appeal to pedestrians (Adkins, Dill, Luhr, \& Neal, 2012). The same dynamics can be observed when looking at the presence of sidewalks: the RDP borough, composed of two former independent cities, has the highest quantity of PCD space, i.e., space shared between pedestrians, cyclists and drivers. This is due to a lot of residential streets not having sidewalks, a unique situation in the study area.

The dynamic nature of street space allocation is also very important when assessing the gap between transportation needs and supply. While exclusive pedestrian space is mostly fixed, space allocated to other modes can vary according to the time of the day, the week, the month or the year. Dynamic allocation currently seems to favor drivers in the downtown area, since the total area of the roadway reallocated from parking to driving lanes is much greater than the one reallocated to transit priority lanes, even if the demand for the latter is much greater. The analysis of parking lanes allocation also shows that while over a quarter of downtown on-street parking space is reallocated to other functions in the AM peak, only half as much is reallocated during the PM peak. This can be explained by a will to balance the needs of commuters with those of shoppers during the later periods of the day.

\subsection{Needs-gap analysis}

Observing the gap between street transportation supply and demand across different boroughs of the city of Montréal highlights a series of imbalances in street space allocation in the study area, but also gaps in the methodological framework of street space allocation assessment.

The most recurrent observation is that the share of city street surfaces provided exclusively to cyclists and bus riders is proportionally lower than the observed demand in almost all boroughs. This is striking, especially since bicycle mode shares are on the rise on the Montréal Island (Vélo Québec, 2016, p. 15) while public transit use is among the strongest in North America (Observatoire Grand Montréal, 2018). Moreover, cycling demand can be expected to be higher in 2018, the reference year for the datasets used to measure street space allocation, than in 2013, the reference year for the estimation of modal shares. Moreover, the OD survey is carried out over the fall and the number of surveyed households increases as the survey period goes on, which tends to skew the mode share of cycling towards its (lower) winter values (Morency et al., 2015). The proportional imbalance of exclusive cycling space allocation is even greater when looking at the potential for cycling using the potential demand profile. This can be explained in part by the fact that only exclusive cycling space-segregated paths and on-street bike lanes - is considered in this paper. Space shared between cyclists and drivers [CD], while legally open to cyclists, has been shown to be avoided by certain categories of cyclists because it constitutes a high-stress type of facility (Dill \& McNeil, 2016). However, this reluctance to ride in space shared with drivers varies with the characteristics of the street (lane width, speed limit) and its traffic volume (Imani, Miller, \& Saxe, 2018), which hints at the relevance of considering some shared space as cycling space in further needs-gap analyses. The same dynamic is at play in the case of public transit: only exclusive bus priority lanes have been considered. This can lead to a distortion in the needs-gap analysis, since buses also have access to the general roadway, although it could be argued that in the congested AM peak period, buses operate at much more inefficient and non-competitive commercial speeds in the absence of dedicated infrastructure.

From a methodological point of view, the use of a needs-gap measure appears as an efficient meth- 
od to represent the consistency between a street's space distribution and its current and potential demand patterns. The modal needs-gap index $\left(\mathrm{G}_{\mathrm{i}}\right)$ developed in this paper should be interpreted with care, especially when considering exclusive pedestrian space. In most boroughs, the portion of street space allocated to exclusive pedestrian use is greater than the observed and even the potential pedestrian demand. This could be interpreted as a sign that pedestrian space in these boroughs should be transferred to other street users since there is what could be considered as an oversupply of pedestrian space. Such a conclusion would ignore important aspects of pedestrian space: sidewalks, like other transportation infrastructure, have minimum design guidelines regarding the width of the walking corridor. Narrower sidewalks could fall under these guidelines, making these sidewalks impractical and possibly dangerous to pedestrians. This hints at the potential of developing more nuanced needs-gap indices that integrate the varying needs and constraints of all transportation modes.

Moreover, the pool of street users for whom streets are designed is also an important consideration to keep in mind. Removing through trips from the street demand in the Ville-Marie borough modified the assessment of the needs-gap between supply and demand. Planners and decision makers should ask themselves which users they should have in mind when designing streets: people who cross the area on their way to another borough, people who participate in different activities within the area, or residents of the area? And should the same street user groups be prioritized in every borough whether central or peripheral? The varying answers to these questions will dictate different approaches to street space allocation.

\subsection{Generalization potential of the needs-gap analysis method}

The needs-gap methodology presented in this paper can be replicated in a diversity of urban contexts, as long as a certain minimal provision of data is available. On the space supply side, a city looking to apply such a needs-gap analysis to its territory should at least have access to datasets that list the locations of transportation facilities for each mode (driving and parking lanes, HOV and transit lanes, cycle lanes and sidewalks). For a static analysis of street space allocation, i.e., one that does not consider the temporal variation due to parking regulations, transit priority lane availability and so on, this could be accomplished with data from OpenStreetMap (OpenStreetMap, 2019), providing that the contributed data is exhaustive. In this scenario, street surfaces could be calculated by estimating widths for each linear street element based on different properties of the street, as done by Szell (2018). In order to capture the dynamic dimension of street space allocation, detailed data has to be collected from the municipal authorities, namely hours of operation of $\mathrm{HOV}$ and transit priority lanes, parking regulations, bikeshare dock activity status and seasonal availability of the cycling network.

On the demand side, the method could be applied using either count data or travel survey data. The use of count data allows for a street-by-street analysis but limits the analysis to certain locations since borough —or citywide counts on every street are rare. Moreover, count data does not allow the analyst to discriminate between internal, external, attracted and produced trips since count data does not provide information on the origin and destination of the observed trip. On the other hand, survey data allows for a deeper analysis of the adequation between street supply and demand according to the origin and destination of the trips. Survey data also offers the opportunity to calculate potential active trips and the associated potential mode shares by taking person-, trip chain- and trip-level information into account. However, the spatial resolution of simulated travel survey trip itineraries does not allow for a street-bystreet analysis, since each trip in the database is weighted by an expansion factor but contains only one origin and destination. For an expansion factor of 25 , for instance, where one recorded trip in the survey sample represents 25 trips in the population, a deterministic shortest-route calculator like OSRM will produce 25 identical trips emanating from the same location at the same time and using the same streets. 
An in-depth, street-by-street analysis of the needs-gap between street supply and demand would thus require spatially and temporally disseminated travel survey data.

\subsection{Limitations}

A certain number of limitations of this paper must be acknowledged. First, the method used to measure street space allocation depends on the accuracy of several datasets that do not share the same update schedule. Most datasets published on the City of Montréal's open data portal are an aggregation of datasets collected by each individual borough, which can mean that the accuracy and reference period of certain street elements - parking regulations, notably — can vary depending on the borough.

This paper also considers all space shared with drivers [CD and PCD] as exclusive automobile space for the purposes of the needs-gap analysis. This could be nuanced, with certain shared spaces being considered as pedestrian or cycling space if it meets low-stress criteria. Also, the mode share used to represent the transportation demand in the needs-gap analysis does not currently include the pedestrian segment of car or bicycle trips, i.e., the pedestrian access and egress that are implicit to anchored modes, although this is very difficult to estimate without data on the parking location associated with these trips. Moreover, this paper looked at the relationship between supply and demand in the streets of the study area on a fall weekday during the AM peak, but the results could be different off-peak, on the weekend or in another season, particularly if driving and parking lanes were analyzed separately.

It should also be noted that the trip data used in this paper comes from a survey that samples only residents of the Greater Montréal area. This means that a number of actual trips are missing from the database, most notably trips carried out by tourists. This could change the portrait of the needs-gap, especially for pedestrian space, in boroughs that attract a lot of tourists like VM or PMR. The survey period extends from September to December, which also has an effect on the mode share of active modes given the increasingly cold weather. Furthermore, phone-based travel surveys using proxy respondents like the OD survey are known to underreport certain categories of trips, especially short, non-work or school-related trips carried out by respondents other than the proxy (Badoe \& Steuart, 2002). Last, but not least, the choice of a borough-level analysis can only give an average view of the needs-gap between supply and demand at the street level within a given borough.

\section{Conclusion}

This paper has shown the potential of applying a needs-gap analysis for the assessment of street space allocation. A detailed database of street space allocation was built using several open and government datasets for a study area composed of 11 boroughs of the city of Montréal. Space allocated to pedestrians, cyclists (moving or parked), drivers (moving or parked) and transit users, as well as sidewalk buffers and medians, was measured for all streets of the study area in an automated manner for different periods of a fall weekday in 2018. A needs-gap analysis was then carried out for each borough in the study area in the AM peak period to assess the gap between street supply, i.e., street space area, and street demand, i.e., passenger-kilometers traveled (PKTs), for three types of street users: pedestrians, cyclists and drivers.

Disparities between space allocation for different street uses were found across the study area as well as between different periods of the day. The largest discrepancy between transportation needs and street space allocation was found to be faced by bus riders and cyclists, with the greatest gaps occurring in the boroughs with the highest observed mode share for these modes. When considering potential transportation demand, the gaps increased across the study area for cycling and decreased for public transit.

Further research will look at the consideration of shared space into the assessment of street space 
allocation. The needs-gap index will be enhanced with the integration of different constraints for each infrastructure type as well. Assessment of the needs-gap at a finer scale, at the corridor and street level, will also be carried out. The impact of weighing the demand profiles with their dynamic space demand will also be ascertained.

\section{Acknowledgements}

The authors wish to acknowledge the support and funding provided by the Fonds de recherche du Québec-Nature et technologies (FRQNT) as well as the industrial partners of the Mobilité Chair: exo, the City of Montréal, the Société de transport de Montréal (STM), the Ministère des Transports du Québec (MTQ) and the Autorité régionale de transport métropolitain (ARTM). 


\section{References}

Adkins, A., Dill, J., Luhr, G., \& Neal, M. (2012). Unpacking walkability: Testing the influence of urban design features on perceptions of walking environment attractiveness. Journal of Urban Design, 17(4), 499-510. https://doi.org/10.1080/13574809.2012.706365

Agentur für clevere Städte. (2014). Wem gehört die stadt? Der flächen-gerechtigkeits. mobilität und flächengerechtigkeit: Eine vermessung Berliner straßen. Agentur für clevere städte. https://www.clevere-staedte. de/files/tao/img/blog-news/dokumente/2014-08-05_Flaechen-Gerechtigkeits-Report.pdf

Badoe, D. A., \& Steuart, G. N. (2002). Impact of interviewing by proxy in travel survey conducted by telephone. Journal of Advanced Transportation, 36(1), 43-62. https://doi.org/10.1002/ atr.5670360104

Berlin's Senate Department for Urban Development and the Environment. (2014). Urban transportation development plan 2025-Sustainable mobility. City of Berlin. Retrieved from https:// www.researchgate.net/publication/265342163_Berlins_Urban_Transportation_Development_ Plan_2025_-_Sustainable_Mobility

Bourbonnais, P.-L. (2019). Kaligrafy/trRouting [C++]. Retrived from https://github.com/kaligrafy/trRouting

Bruun, E. C., \& Vuchic, V. R. (1995). Time-area concept: Development, meaning and applications. Transportation Research Record, 1499, 95-104. Retrieved from https://trid.trb.org/view/452722

Colville-Andersen, M. (2018). Copenhagenize: The definitive guide to global bicycle urbanism. Washington, DC: Island Press.

Communauté métropolitaine de Montréal. (n.d.). Indice canopée métropolitain. Observatoire Grand Montréal. Retrieved from http://observatoire.cmm.qc.ca/fileadmin/user_upload/carte/ canope/2017/IC_TIFF/660_IndiceCanopee_2017_TIF.zip

Communauté urbaine de Bordeaux. (2000). Se déplacer. Plan des déplacements urbains 2000-2005. Retrieved from https://participation.bordeaux-metropole.fr/sites/default/files/bordeaux_metropole/ bordeaux_metropole_389.pdf

Currie, G. (2010). Quantifying spatial gaps in public transport supply based on social needs. Journal of Transport Geography, 18(1), 31-41. https://doi.org/10.1016/j.jtrangeo.2008.12.002

Di Ciommo, F., \& Shiftan, Y. (2017). Transport equity analysis. Transport Reviews, 37, 139-151. https:// doi.org/10.1080/01441647.2017.1278647

Dill, J., \& McNeil, N. (2016). Revisiting the four types of cyclists: Findings from a national survey. Transportation Research Record, 2587(1), 90-99. https://doi.org/10.3141/2587-11

exo. (n.d.). Enquête OD 2013. exo. Retrieved from https://exo.quebec/fr/a-propos/portrait-mobilite/ enquete-od-2013

Gössling, S., Schröder, M., Späth, P., \& Freytag, T. (2016). Urban space distribution and sustainable transport. Transport Reviews, 36, 659-679. https://doi.org/10.1080/01441647.2016.1147101

Hampton, S. (2013). Measuring Oklahoma main streets. Institute for Quality Communities blog. Retrieved from http://iqc.ou.edu/2013/08/19/mainstreets/

Hebbert, M. (2005). Engineering, urbanism and the struggle for street design. Journal of Urban Design, 10, 39-59. http://dx.doi.org/10.1080/13574800500062361

Hui, N., Saxe, S., Roorda, M., Hess, P., \& Miller, E. J. (2018). Measuring the completeness of complete streets. Transport Reviews, 38, 73-95. https://dx.doi.org/10.1080/01441647.2017.1299815

Imani, A. F., Miller, E. J., \& Saxe, S. (2018). Cycle accessibility and level of traffic stress: A case study of Toronto. Paper presented at the Transportation Research Board 97th Annual Meeting. Retrieved from https://trid.trb.org/view/1496662 
Lee, R. J., Sener, I. N., \& Jones, S. N. (2017). Understanding the role of equity in active transportation planning in the United States. Transport Reviews, 37(2), 211-226. https://doi.org/10.1080/014416 47.2016.1239660

Luxen, D., \& Vetter, C. (2011). Real-time routing with OpenStreetMap data. Proceedings of the 19th ACM SIGSPATIAL International Conference on Advances in Geographic Information Systems, 513516. https://doi.org/10.1145/2093973.2094062

Martin, T. (2016). Exploration de données spatiales pour l'analyse des victimes routières et du partage de la rue [Mémoire de maîtrise, École Polytechnique de Montréal]. Retrieved from https://publications. polymtl.ca/2132/

Morency, C., Verreault, H., Bourdeau, J.-S., Frappier, A., Faucher, J., \& Bahbouh, K. (2015). Assistance méthodologique pour le traitement et l'analyse des données des enquêtes Origine-destination québécoises pour dresser le portrait du Vélo au Québec en 2015 (p. 179). Montréal: Polytechnique Montréal. Retrieved from https://www.velo.qc.ca/wp-content/uploads/2020/01/vq-edv2015-analyseenqueteod. pdf

Morency, C., Verreault, H., \& Frappier, A. (2019). Estimating latent cycling and walking trips in Montreal. International Journal of Sustainable Transportation, 14(5), 349-360. https://doi.org/10.1080/1 5568318.2018.1558467

Observatoire Grand Montréal. (2018). Déplacements domicile-travail dans le Grand Montréal: Faible progression du transport durable depuis 2001 (No. 35; Perspective Grand Montréal, p. 8). Communauté métropolitaine de Montréal. Retrieved from https://cmm.qc.ca/documentation/perspective-grandmontreal/perspective-grand-montreal-no35/

OpenStreetMap. (2019, July 18). Map features_-Highway [Wiki]. OpenStreetMap Wiki. Retrieved from https://wiki.openstreetmap.org/wiki/Map_Features\#Highway

Secrétariat à l'enquête Origine-Destination. (2015). Enquête origine-destination 2013. La mobilité des personnes dans la région de Montréal: Faits saillants. secrétariat à l'enquête origine-destination. Retrieved from https:/exo.quebec/fr/a-propos/portrait-mobilite/enquete-od-2013

Statistics Canada. (n.d.). Focus on geography series, 2016 census - Census metropolitan area of Montréal. Statistique Canada. Retrieved from https://www12.statcan.gc.ca/census-recensement/2016/ as-sa/fogs-spg/Facts-cma-eng.cfm?LANG=Eng\&GK=CMA\&GC=462\&TOPIC=1

Szell, M. (2018). Crowdsourced quantification and visualization of urban mobility space inequality. Urban Planning, 3(1), 1-20. http://dx.doi.org/10.17645/up.v3i1.1209

van Liere, B., Beens, O., \& Knol, A. (2017). Van wie is de stad? (p. 14). Milieudefensie. Retrieved from https://milieudefensie.nl/actueel/van-wie-is-de-stad-pdf/view

Vélo Québec. (2016). Cycling in Québec in 2015 (p. 15). Vélo Québec. Retrieved from velo.qc.ca/cycling 2015

Ville de Montréal. (n.d.-a). Arbres publics sur le territoire de la Ville. Données ouvertes Montréal. Retrieved from https://donnees.montreal.ca/ville-de-montreal/arbres

Ville de Montréal. (n.d.-b). Arceaux à vélos. Données ouvertes Montréal. Retrieved from https://donnees.montreal.ca/ville-de-montreal/arceaux-velos

Ville de Montréal. (n.d.-c). BIXI - État des stations. Données ouvertes Montréal. Retrieved from https:// donnees.montreal.ca/bixi/bixi-etat-des-stations

Ville de Montréal. (n.d.-d). Chaussée agrégée et intersection (Base de données des actifs de voirie). Données ouvertes Montréal. Retrieved from https://donnees.montreal.ca/ville-de-montreal/voirie-chausseeintersection

Ville de Montréal. (n.d.-e). Géobase-Réseau routier. Données ouvertes Montréal. Retrieved from https://donnees.montreal.ca/ville-de-montreal/geobase 
Ville de Montréal. (n.d.-f). Limite administrative de l'agglomération de Montréal (Arrondissements et Villes liées). Données ouvertes Montréal. Retrieved from https://donnees.montreal.ca/ville-de-montreal/ polygones-arrondissements

Ville de Montréal. (n.d.-g). Réseau cyclable. Données ouvertes Montréal. Retrieved from https://donnees.montreal.ca/ville-de-montreal/pistes-cyclables

Ville de Montréal. (n.d.-h). Signalisation (stationnement sur rue). Données ouvertes Montréal. Retrieved from https://donnees.montreal.ca/ville-de-montreal/stationnement-sur-rue-signalisation-courant

Ville de Montréal. (n.d.-i). Stationnements municipaux tarifés, sur rue et hors rue. Données ouvertes Montréal. Retrieved from https://donnees.montreal.ca/agence-de-mobilite-durable/stationnements-municipaux-tarifes-sur-rue-et-hors-rue 